\title{
Transfusion-related Acute Lung Injury During Intravenous Immunoglobulin Treatment
}

PARASKEVI V. VOULGARI, MD, Assistant Professor of Rheumatology; SOPHIA PASCHOU, MD, Fellow in Rheumatology, Rheumatology Clinic, Department of Internal Medicine, University of Ioannina; EVGENIA SVARNA, MD, Registrar in Radiology, Department of Imaging and Radiology, Medical School; NIKI TSIFETAKI, MD, Registrar in Rheumatology; ALEXANDROS A. DROSOS, MD, FACR, Professor of Medicine/Rheumatology, Rheumatology Clinic, Department of Internal Medicine, University of Ioannina, Greece. Address correspondence to Dr. Drosos. E-mail: adrosos@cc.uoi.gr. J Rheumatol 2010;37:190-1; doi:10.3899/jrheum.090725

A 71-year-old woman with Sjögren's syndrome and giant cell arteritis was treated with intravenous immunoglobulin (IVIG) $(6 \mathrm{~g}$ protein/250 $\mathrm{ml}$, stabilized with sucrose $10 \mathrm{~g} / \mathrm{fla}-$ con, $\mathrm{NaCl} 0.02 \mathrm{~g} / \mathrm{g}$ protein) for peripheral sensory motor neuropathy - an unlabeled use of the $\operatorname{drug}^{1,2}$.

The dose of IVIG was $400 \mathrm{mg} / \mathrm{kg} /$ day for 5 days. During administration of the third flacon of IVIG (12 grams had been already infused over 4 hours with an infusion rate $\sim 2.1$ $\mathrm{ml} / \mathrm{min}$ ), the patient presented increasing dyspnea. Physical examination showed bilateral rales, a pulse of 95 beats per min and blood pressure of $130 / 70 \mathrm{mmHg}, \mathrm{PO}_{2}$ of 45.7 torr, and Sat $\mathrm{O}_{2} 83.8 \%$. A chest radiograph showed interstitial and airspace infiltrates. IVIG was discontinued. Computed tomography (CT) of the chest revealed alveolar infiltrates bilaterally (Figure 1). Transfusion-related acute lung injury (TRALI) was diagnosed based on acute respiratory distress, bilateral lung infiltrations in the radiograph (which occurred within $6 \mathrm{~h}$ of transfusion of IVIG), hypoxemia, Sat $\mathrm{O}_{2}<$ $90 \%$, and no evidence of transfusion-associated cardiogenic lung edema, anaphylactic reaction, or sepsis. Other risk factors for acute lung injury (aspiration, pneumonia, toxic inhalation, lung contusion, shock) were excluded ${ }^{3}$. The patient was treated with a continuous positive airway pressure mask maintaining saturation above $90 \%$. There was a
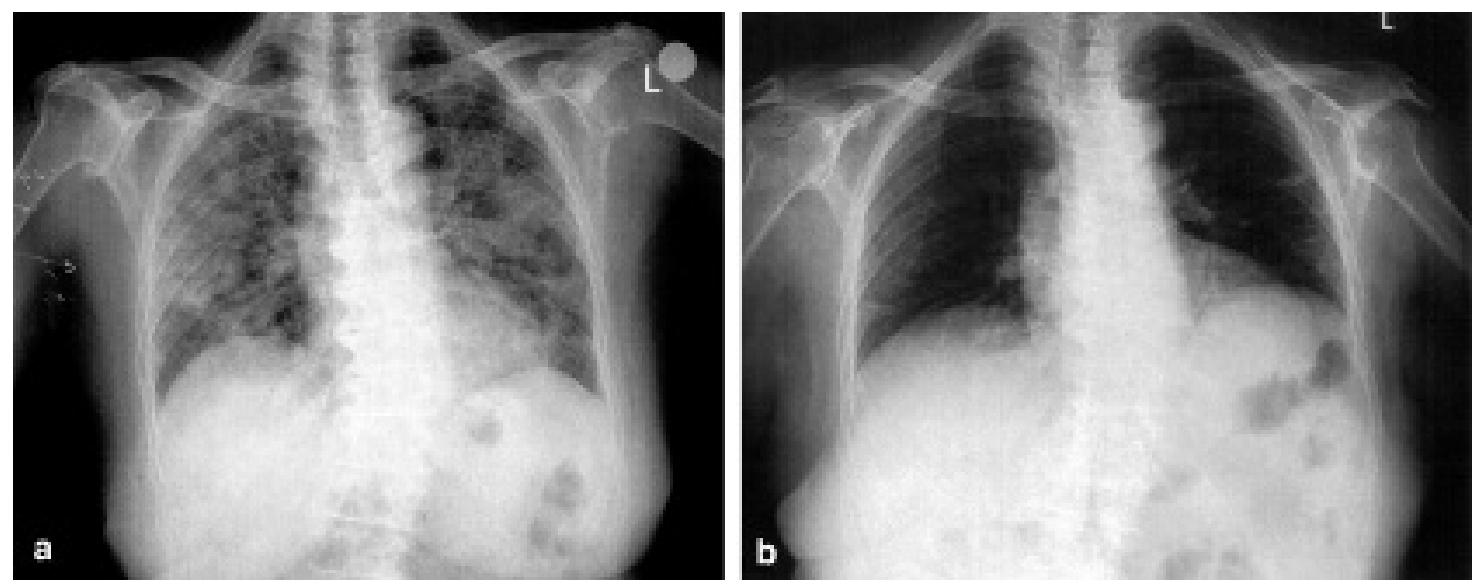

Figure 1. (A) Extensive coalescent airspace infiltrates bilaterally. (B) Great improvement of the radiological findings of the lungs.
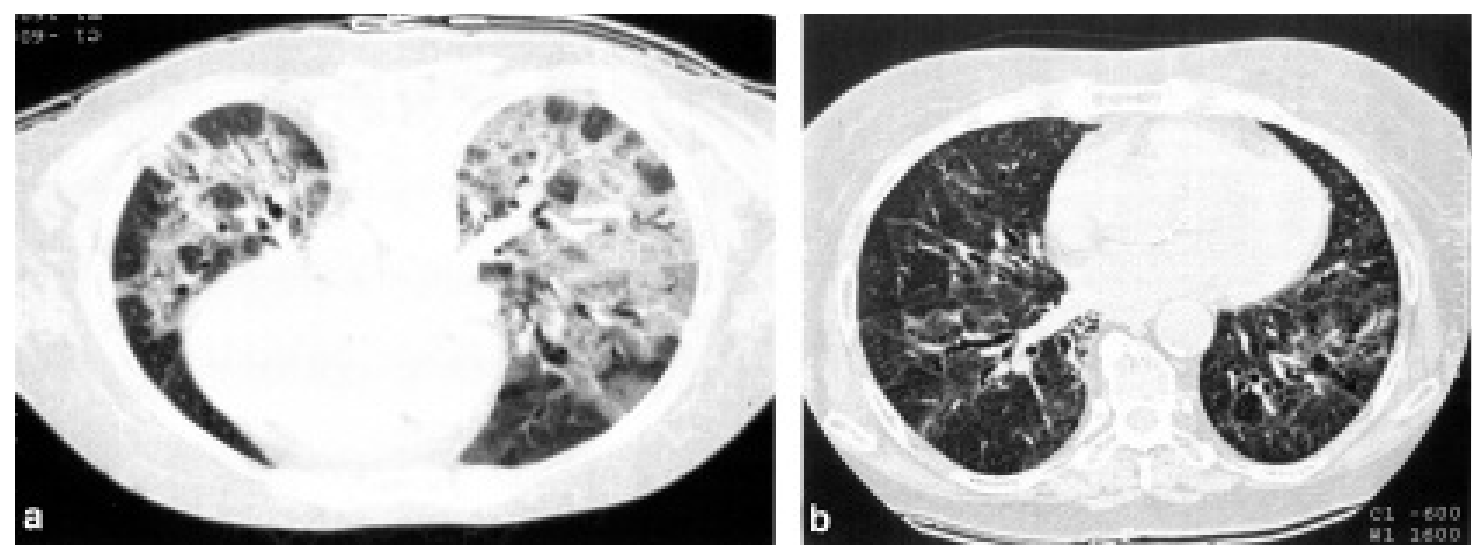

Figure 2. (A) Computed tomography of the thorax: coalescent pulmonary infiltrates and areas with ground glass appearance. (B) Areas of ground glass appearance in the position of preexisting infiltrates. Existence of bronchiectasis in the same area. 
gradual improvement of arterial blood gas and CT findings during the next 4 weeks (Figure 2).

Few cases of TRALI after IVIG have been described ${ }^{4}$. Leukocyte antibodies and neutrophil priming agents released in stored cellular blood components have been considered causative. The mainstay of therapy is oxygen and when needed, ventilatory support. The presence of neutrophil antibodies in the IVIG and cognate neutrophil antigens in the patient were not investigated. According to the published criteria ${ }^{5}$, although her clinical course was atypical, this case strongly suggests TRALI after IVIG.

\section{REFERENCES}

1. Morozumi S, Kawagashira Y, Iijima M, Koike H, Hattori N, Katsuno M, et al. Intravenous immunoglobulin treatment for painful sensory neuropathy associated with Sjögren's syndrome. J Neurol Sci 2009;279:57-61.

2. García Gasalla M, Yebra Bango M, Vargas Núñez JA, Mellor Pita S, Garcia Alvarado M, de Abajo Alonso A, et al. Giant cell arteritis associated with demyelinating polyradiculoneuropathy. Ann Rheum Dis 2001;60:812-3.

3. Bux J, Sachs UJ. The pathogenesis of transfusion-related acute lung injury (TRALI). Brit J Haematol 2007;136:788-99.

4. Rizk A, Gorson KC, Kenney L, Weinstein R. Transfusion-related acute lung injury after the infusion of IVIG. Transfusion 2001;41:264-8.

5. Kleinman S, Caulfield T, Chan P, Davenport R, McFarland $\mathrm{J}$, McPhedran S, et al. Toward an understanding of transfusion-related acute lung injury: statement of a consensus panel. Transfusion 2004;44:1774-89. 